\title{
CORRECTION
}

\section{Correction: The GNE-KLH anti-cocaine vaccine protects dams and offspring from cocaine-induced effects during the prenatal and lactating periods}

Paulo Sérgio de Almeida Augusto (D), Raissa Lima Gonçalves Pereira (D), Sordaini Maria Caligiorne (D), Brian Sabato (iD), Bruna Rodrigues Dias Assis (D), Larissa Pires do Espírito Santo (D), Karine Dias dos Reis (D), Gisele Assis Castro Goulart (iD), Ângelo de Fátima (D), Maila de Castro Lourenço das Neves (iD) and Frederico Duarte Garcia (iD)

(c) The Author(s), under exclusive licence to Springer Nature Limited 2021

Molecular Psychiatry (2021) 26:7792; https://doi.org/10.1038/s41380-021-01305-9

Correction to: Molecular Psychiatry https://doi.org/10.1038/s41380-

021-01210-1, published online 11 August 2021
After publication the authors requested the addition of the text 'Supported by the Pró-Reitoria de Pesquisa (PRPq) da Universidade Federal de Minas Gerais' in order to comply with institutional funding requirements. The original article has been corrected. 